\title{
Influence of Metal Ions on Hydrogen Production by Photosynthetic Bacteria Grown in Escherichia coli Pre-Fermented Cheese Whey
}

\author{
Fadhil M. Salih ${ }^{1^{*}}$, Muthana I. Maleek ${ }^{2}$ \\ ${ }^{1}$ ClearValue Technologies Inc., Sugar Land, U.S.A.; ${ }^{2}$ Department of Biology, College of Science, Wasit University, Wasit, Iraq. \\ Email: fadhilsalih@gmail.com
}

Received September $15^{\text {th }}, 2010$; revised October $4^{\text {th }}, 2010$; accepted October $15^{\text {th }}, 2010$.

\begin{abstract}
The photosynthetic bacteria, Rodospirillum rubrum, produced hydrogen when grown in cheese whey in presence of light. The production increased three times as much when whey was used after being incubated in presence of Escherichia coli at $37^{\circ} \mathrm{C}$ for 5 days, giving a total of $3600 \mathrm{ml}$ of $\mathrm{H}_{2}$ in 10 days. The presence of Fe ions $(5 \mathrm{mg} / \mathrm{L})$ enhanced $\mathrm{H}_{2}$ production of treated whey to about $6000 \mathrm{ml}$ in 10 days. Mo ions $(0.3$ and $1.6 \mathrm{mg} / \mathrm{l})$ did not affect achieved $\mathrm{H}_{2}$ production of treated whey. However, when Fe and Mo ions were present together, the production was comparable with that of Mo ions alone, i.e. Mo prevented Fe of producing any enhancing effect. The addition of Mn ions $(7.68 \mathrm{mg} / \mathrm{L})$ to treated whey containing $\mathrm{Fe}(5 \mathrm{mg} / \mathrm{L})$ and Mo ions $(8 \mathrm{mg} / \mathrm{L})$ increased $\mathrm{H}_{2}$ production to give about $9500 \mathrm{ml} / 10$ days.
\end{abstract}

Keywords: Hydrogen Production, Photosynthetic Bacteria, Rodospirillum rubrum, Metal Ions, E. coli, Fermentation

\section{Introduction}

Hydrogen is an attractive energy carrier because it has the highest density of energy per weight of any chemical fuel. It is essentially non-polluting and it is by far the most abundant element in the universe [1]. Among the many methods used for hydrogen production are those depending on biological systems. The light dependent production of hydrogen by photosynthetic bacteria, which was first discovered in 1949 with cultures of $R$. rubrum [2] and with other photosynthetic bacteria [3] represents one of the promising systems. It has been found that in photosynthetic bacteria including $R$. rubrum energy dependent hydrogen production occurs for which the nitrogenase enzyme is responsible and such production increased by intracellular accumulation of nitrogenases [4] and [5]. The activity of the enzyme was strictly dependent on light and no activity was observed in the dark [6].

Maximal expression of $\mathrm{H}_{2}$ production capacity was observed when bacteria were grown photoheterotrophically on suitable substrates (e.g. organic acids) in presence of certain amino acids serving as source of nitrogen [7] and [8]. However, presence of ammonia, even at very low concentrations repressed synthesis of $\mathrm{H}_{2}$ evolving system and inhibited $\mathrm{H}_{2}$ production [9] and [10]. Nevertheless, addition of $\mathrm{N}_{2}$ gas at intervals activates $\mathrm{H}_{2}$ production [3]. Evolution of $\mathrm{H}_{2}$ increased twice as high when $5 \mathrm{mg}$ iron/L was present as compared to cultures containing $0.5 \mathrm{mg} / \mathrm{L}$. This phenomenon was reportedly related to iron requirement of nitrogenase and ferredoxin [11]. Molybdenum and iron were also necessary for nitrogenase activity through its two proteins ( $\mathrm{Fe}$ and $\mathrm{Mo} \mathrm{Fe}$ proteins) [12]. Other factors that seriously affect the process of conversion such as inoculum, substrate, reactor type, phosphate, metal ion, temperature and $\mathrm{pH}$ are reported elsewhere [13].

Cheese whey has been used successfully as a growth supporting medium as for its good contents of nutritive materials in addition to its high content of lactose (5 to $6 \%$ [14]. Growing $R$. rubrum in cheese whey in presence of light produced $\mathrm{H}_{2}$ gas at certain rate [15] and [16]. Similarly, hydrogen was also produced from cheese whey and other waste materials using anaerobic and photosynthetic bacteria [17] and [18]. Usually large amount of cheese whey is released from dairy factories to sewage every day. Therefore, it was the aim of the present investigation to make use of this whey in the production of $\mathrm{H}_{2}$ through growing photosynthetic bacteria and to try to improve such productivity. 


\section{Materials and Methods}

R. rubrum S-1 was used. Cells were grown and propagated using RCV medium described by Weaver et al. [12] except that ammonia was replaced by $7 \mathrm{mM} \mathrm{L}$-serine and the DL-malic acid by $30 \mathrm{mM}$ lactic acid. For the rest of the work cheese whey was used as nutrient medium. It was obtained from a dairy factory immediately before the release to sewage. Prior to using the whey it was heat treated at $95^{\circ} \mathrm{C}$ for 15 minutes and filtered through cheesecloth. After heat treatment whey was centrifuged in 50 $\mathrm{ml}$ lots at $3000 \mathrm{rpm}$ for 30 minutes in order to get rid of most of the solid particles. $\mathrm{pH}$ was adjusted to 7.0 using $1 \mathrm{~N} \mathrm{NaOH}$ and samples were further autoclaved at $121^{\circ} \mathrm{C}$ for 15 minutes.

In order to convert the lactose of the whey into lactic acid, whey was incubated at $37^{\circ} \mathrm{C}$ for 5 days in presence of E. coli. After treatment whey was centrifuged for 30 minutes and the supernatant was heat treated at $80^{\circ} \mathrm{C}$ for 10 minutes to kill $E$. coli left. Whey $\mathrm{pH}$ was adjusted to 7.0.

Screw capped test tubes containing $27 \mathrm{ml} \mathrm{RCV} \mathrm{me-}$ dium was inoculated with $R$. rubrum and incubated at $30^{\circ} \mathrm{C}$ overnight in presence of light $(60 \mathrm{~W}, 25 \mathrm{~cm}$ distance). Two subcultures were made successively by $7 \mathrm{ml}$ inoculums. This method of subculturing was employed for bacterial adaptation. The content of the third culture was transferred to $125 \mathrm{ml}$ bottle containing about $100 \mathrm{ml}$ medium so that the bottle was topped up. The bottle was closed with rubber stopper leaving a small space above the medium for gas collection. Needle was inserted through the stopper so that its distal end does not touch the liquid. The needle was connected to a rubber tube for gas collection. Gas collection was made by simple liquid displacement. The liquid was distilled water containing $40 \mathrm{~g} \mathrm{NaOH}$ and $200 \mathrm{~g} \mathrm{NaCl} / \mathrm{l}$. It was convenient for removing $\mathrm{CO}_{2}$ completely from the evoluted gas. The efficiency of $\mathrm{CO}_{2}$ removal was checked using gas chromatography (Shimadzu GC 14A Gas Chromatograph). The bottle was incubated at $30^{\circ} \mathrm{C}$ in a growth box made of Perspex and illuminated with $2 \times 60 \mathrm{~W}$ Tungsten lamps.

Growth intensity was measured by using PYE Unicum SP8-200 UV/VIS spectrophotometer. It was found in the range of 2.45 at $660 \mathrm{~nm}$ and giving a dry weight of $0.00141 \mathrm{~g} / \mathrm{ml}$ for one-day-old culture. Light intensity was measured by IL 700 A Research Radiometer, International Light, Newburyport, Ma, USA. It was found to be $20 \mathrm{~mW} / \mathrm{cm}^{2} . \mathrm{H}_{2}$ concentration was determined using gas chromatography as well. The gas chromatograph was equipped with a molecular sieve 5A column (40-60 mesh) and a thermal conductivity detector.
For the purpose of increasing the efficiency of whey, varying concentrations of $\mathrm{Fe}(5,10$ and $20 \mathrm{mg} / \mathrm{L})$, Mo $(0.8,1.6,4$ and $8 \mathrm{mg} / \mathrm{L})$ and $\mathrm{Mn}(2.58-5.12$ and 7.68 $\mathrm{mg} / \mathrm{L}$ ) were added either individually or in combinations.

\section{Results and Discussion}

R. rubrum seeded in treated or untreated whey showed heavy growth in comparison with that grown on RCV medium (Figure 1). As appeared, cells produced $\mathrm{H}_{2}$ from both untreated and treated whey. For untreated one the average rate of $\mathrm{H}_{2}$ production during the first 2 days was $120 \mathrm{ml} / \mathrm{L}$ medium/day, and for the first 5 days was 160 $\mathrm{ml} / \mathrm{L} /$ day followed by slower rate. However, when E. coli treated whey was used, the rate of $\mathrm{H}_{2}$ production was about $820 \mathrm{ml} / \mathrm{L} /$ day for the first 2 days, and was as high as $560 \mathrm{ml} / \mathrm{L} /$ day in the first 5 days, followed by slower rate.

For comparison purposes $\mathrm{H}_{2}$ produced by cells grown in RCV medium was also included in Figure 1. The rates of production for the first 2 days were 300 and 450 $\mathrm{ml} / \mathrm{L} /$ day respectively. Production continued at its high rate up to the eighth day where it almost stopped. The total amounts of $\mathrm{H}_{2}$ produced during the whole experimental period (10 days) were 960,3040 and $3600 \mathrm{ml}$ for untreated whey, RCV medium and treated whey, respectively.

The low productivity of untreated whey can be attributed to the unavailability of readily useable carbohydrates (the major part of carbohydrate was lactose, which simply, cannot be directly used by this bacteria) [15] and [16]. However, the evoluted $\mathrm{H}_{2}$ may well be due to the presence of small amount of lactic acid formed during cheese curding [14]. This seems unreal because when lactate and glutamate were added to the untreated whey (Figure 2) $\mathrm{H}_{2}$ production was not improved. In fact lower evolution was seen. However, when whey contained $50 \% \mathrm{RCV}$ medium $\mathrm{H}_{2}$ production was enhanced to an extent as high as that of the E. coli treated whey. These findings imply that the improvement of $\mathrm{H}_{2}$ production in treated whey could possibly not be due to lactic acid formation only, but to other product(s) formed as a result of $E$. coli growth in the whey.

When ferric chloride at 5,10 and $20 \mathrm{mg} / \mathrm{L}$ was added to $E$. coli treated whey, $\mathrm{H}_{2}$ production was largely affected (Figure 3). At $10 \mathrm{mg} / \mathrm{L}$ the total amounts of $\mathrm{H}_{2}$ evoluted in 10 days was unchanged but the rate of evolution was altered. $\mathrm{H}_{2}$ production at $5 \mathrm{mg} / \mathrm{L}$ was largely enhanced giving a total of $6000 \mathrm{ml} / \mathrm{L} / 10$ days. The rates of production at the first 2 and 5 days were 1600 and 935 $\mathrm{ml} / \mathrm{L} /$ day, respectively. This amount of increase is about 


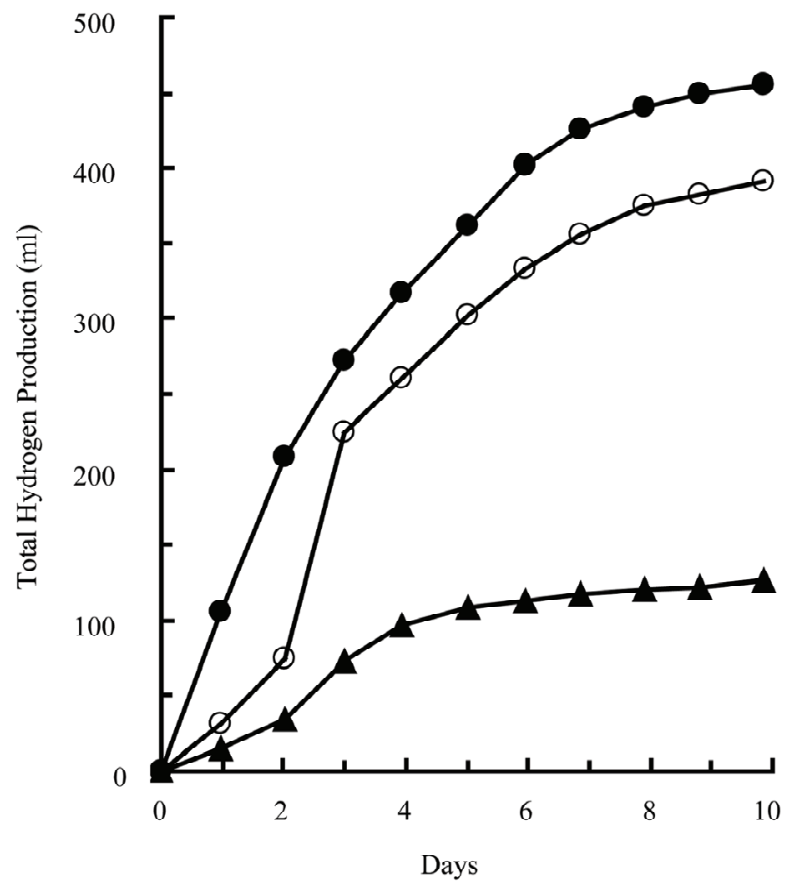

Figure 1. $\mathrm{H}_{2}$ production from $125 \mathrm{ml}$ cultures of $\mathrm{R}$. rubrum grown in untreated whey, $\Delta ; E$. coli treated whey, $\bullet$; and RCV medium, ○.

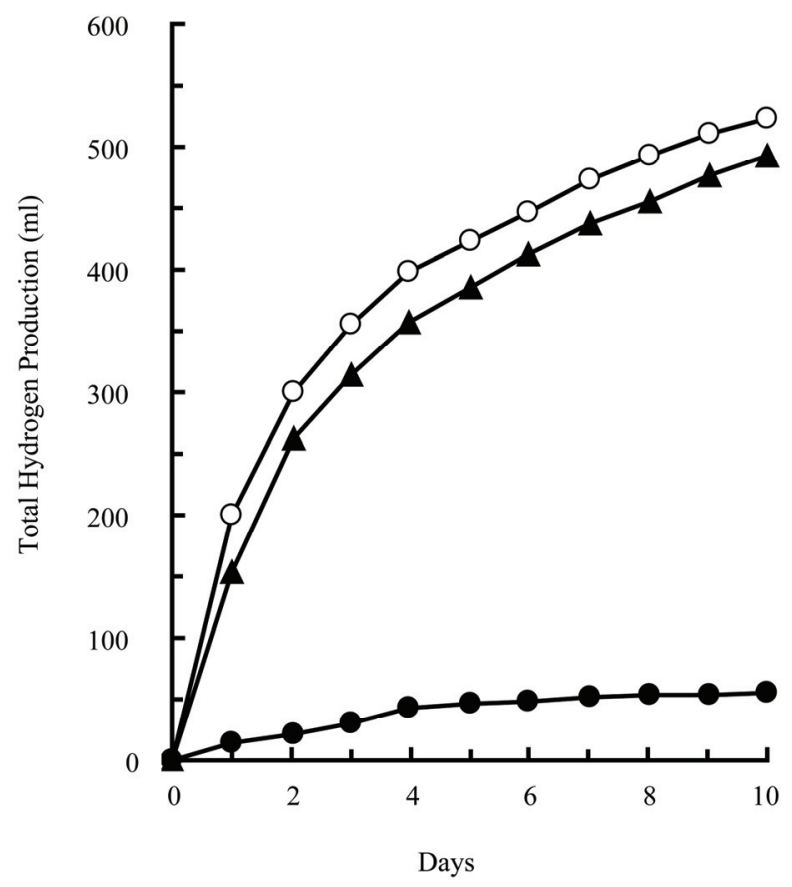

Figure 2. $\mathrm{H}_{2}$ production from $125 \mathrm{ml}$ untreated whey cultures to which RCV medium $(\circ)$, lactate $(\bullet)$ or lactate + Glutamate $(\Delta)$ was added.

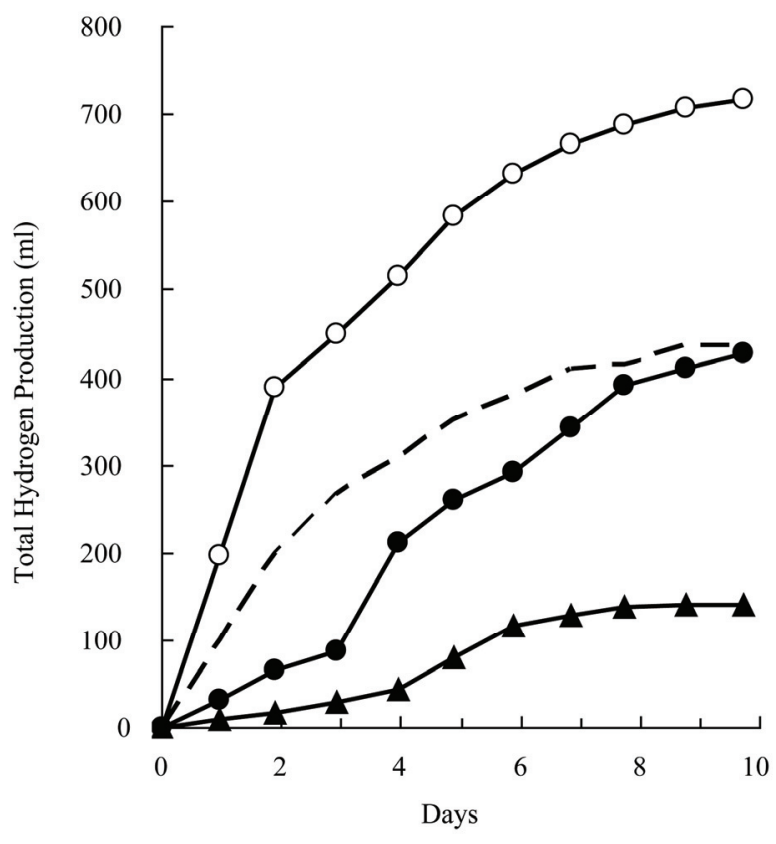

Figure 3. Ferric ion effect on $\mathrm{H}_{2}$ production from $125 \mathrm{ml}$ untreated whey cultures containing $5 \mathrm{mg} / \mathrm{L}(\circ), 10 \mathrm{mg} / \mathrm{L}(\bullet)$ or $20 \mathrm{mg} / \mathrm{L}$. Dashed line represents treated whey alone.

double the amount produced by the treated whey alone. However when $20 \mathrm{mg} / \mathrm{L}$ ferric chloride was used, marked production in $\mathrm{H}_{2}$ evolution was seen giving a total $\mathrm{H}_{2}$ of $1200 \mathrm{ml} / \mathrm{L}$ in 10 days period. The increased production of $\mathrm{H}_{2}$ due to the presence of $5 \mathrm{mg} \mathrm{Fe} / \mathrm{L}$ can be taken in support of a previous work [11], in which this phenomenon was related to iron requirement for nitrogenase and ferredoxin. However, reduction in $\mathrm{H}_{2}$ production at higher ferric chloride concentrations may be due to cellular intoxication that was easily detected by the poor growth seen in cultures containing these concentrations.

Figure 4 shows the changes in $\mathrm{H}_{2}$ production from treated whey containing sodium molybdate at 0.3 and 1.6 $\mathrm{mg} / \mathrm{L}$. It is apparent that the presence of molybdate enhanced both the rate and the total $\mathrm{H}_{2}$ production. The average daily production at the first 2 days for 0.3 and $1.6 \mathrm{mg} / \mathrm{L}$ were 1050 and $1200 \mathrm{ml} / \mathrm{L}$, respectively. The rates for the first 5 days for the two molybdate concentrations were 625 and $680 \mathrm{ml} / \mathrm{L} / \mathrm{day}$, and the total amounts produced were 3920 and $4200 \mathrm{ml}$, respectively.

Changes in $\mathrm{H}_{2}$ production from treated whey containing iron and molybdate together (Figure 5) were not significantly different from those seen when molybdate alone was present (Figure 4). In other words molybdate abolished the enhanced $\mathrm{H}_{2}$ production exerted by ferric chloride $(5 \mathrm{mg} / \mathrm{l})$. No possible explanation can now be offered for this discrepancy. 


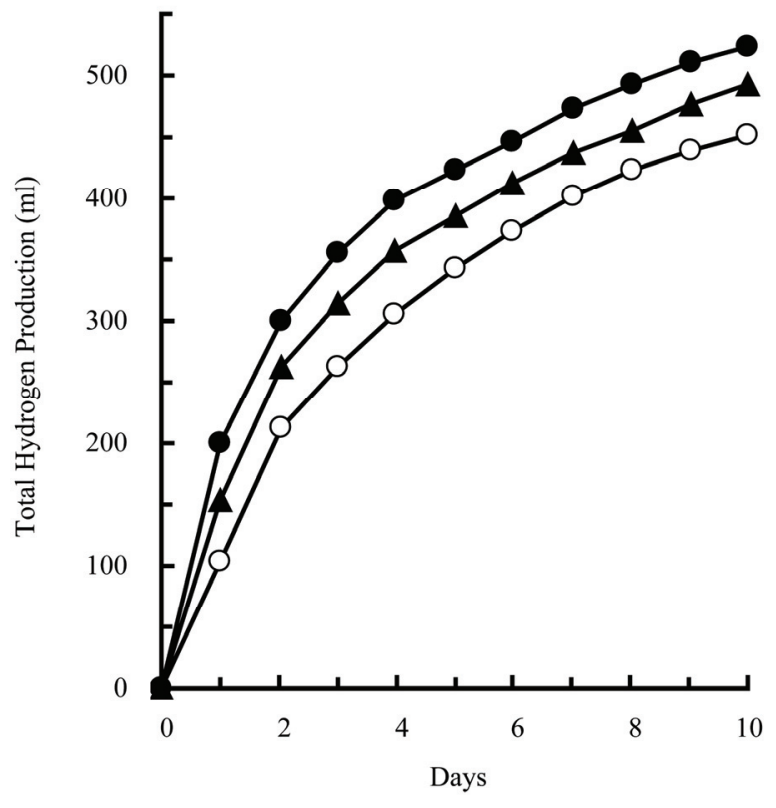

Figure 4. Effects of adding Mo ions to $E$. coli treated whey on $\mathrm{H}_{2}$ production. Treated whey alone $(\circ), 0.8 \mathrm{mg} \mathrm{Mo} / \mathrm{L}(\dot{\Delta})$ or $1.6 \mathrm{mg} \mathrm{Mo} / \mathrm{L}(\bullet)$.

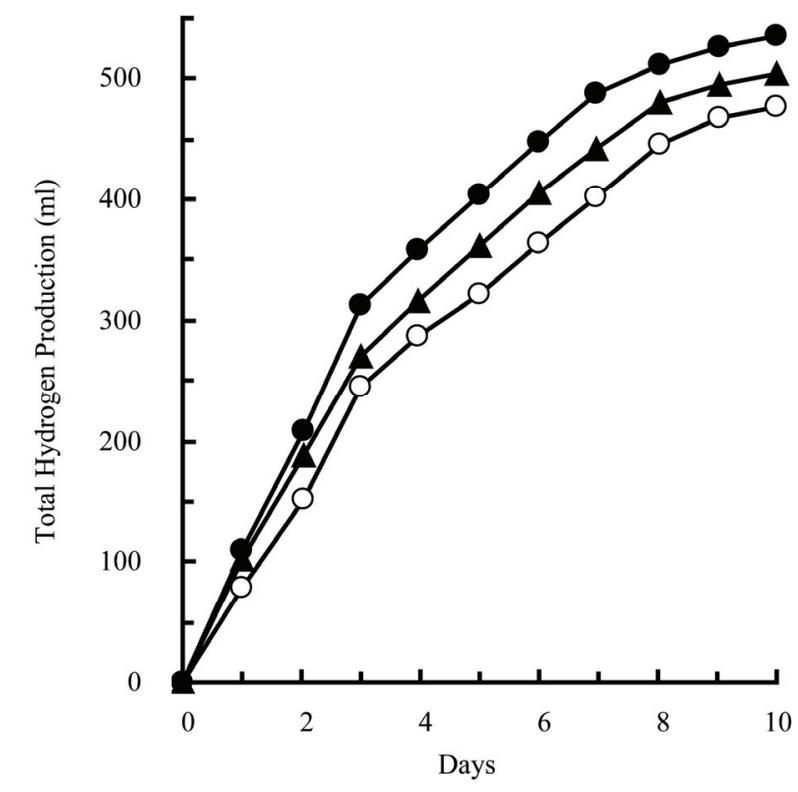

Figure 5. Effects of adding Mo ions to treated whey containing $5 \mathrm{mg} \mathrm{Fe} / \mathrm{L}+1.6 \mathrm{Mo} / \mathrm{L} \mathrm{(O),} 4 \mathrm{mg} \mathrm{Mo} / \mathrm{L} \mathrm{( \Delta )} \mathrm{or} 8 \mathrm{mg}$ Mo/L (•).

Large increase in the rate and total amount of $\mathrm{H}_{2}$ produced was seen when manganese sulphate was added to treated whey containing $5 \mathrm{mg}$ iron/L and $8 \mathrm{mg} \mathrm{Mo} / \mathrm{L}$ (Figure 6). At $2.65 \mathrm{mg} \mathrm{Mn} / \mathrm{L}$ the rate of $\mathrm{H}_{2}$ production at

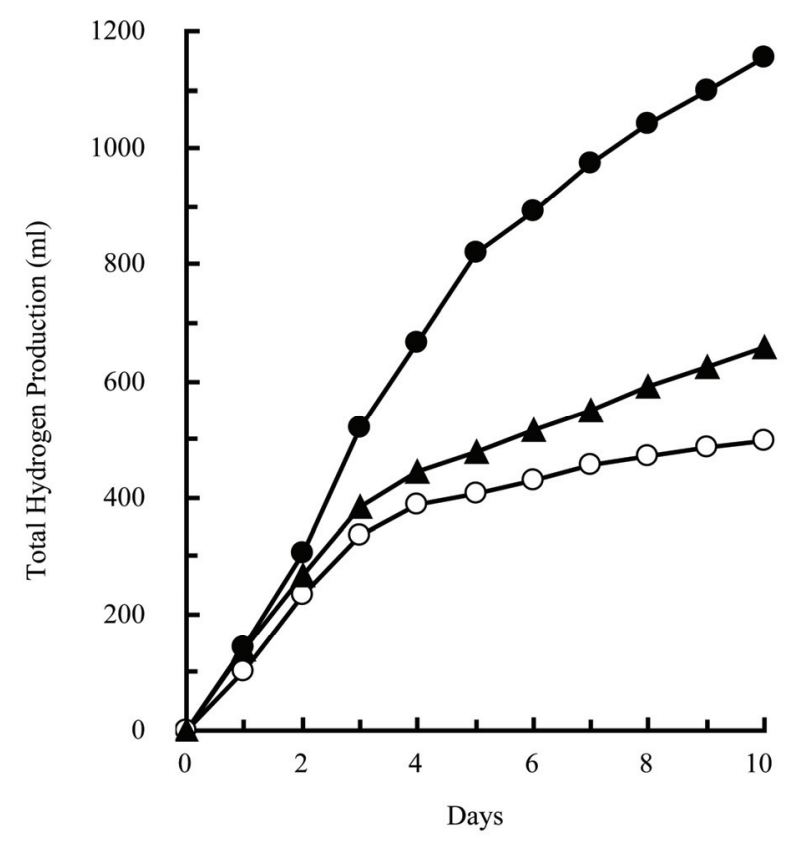

Figure 6. Effects of adding Mn ions to treated whey containing $5 \mathrm{mg} \mathrm{Fe} / \mathrm{L}+8 \mathrm{mg} \mathrm{Mo} / \mathrm{L}$ on hydrogen production. $2.58 \mathrm{mg} \mathrm{Mn} / \mathrm{L}(\circ), 5.12 \mathrm{mg} \mathrm{Mn} / \mathrm{L}(\Delta)$ or $7.68 \mathrm{mg} \mathrm{Mn} / \mathrm{L}(\bullet)$.

the first 2 days was $900 \mathrm{ml} / \mathrm{L} /$ day and at the first 5 days was $655 \mathrm{ml} / \mathrm{L} /$ day, giving a total 10 days production of $4000 \mathrm{ml}$. For Mn concentration of $5.12 \mathrm{mg} / \mathrm{L}$ the rate at the first 2 days was $1000 \mathrm{ml} / \mathrm{L} /$ day and at the first 5 days was $760 \mathrm{ml} / \mathrm{L} /$ day, with a total production in 10 days of $5400 \mathrm{ml}$. Much higher rates and total production were obtained when $7.68 \mathrm{mg} \mathrm{Mn} / \mathrm{L}$ was used; rate at first 2 days was $1335 \mathrm{ml} / \mathrm{L} /$ day and the total 10 days production was $9500 \mathrm{ml}$. It is apparent that curves representing the effect of the presence of the three ions (Figure 6) indicate that high $\mathrm{Mn}$ concentration $(7.68 \mathrm{mg} / \mathrm{L})$ increased $\mathrm{H}_{2}$ production by keeping up the initial high production rate to continue for a period longer than that occurred at lower Mn concentration. In fact, after 3 days the rate of $\mathrm{H}_{2}$ production for the two low $\mathrm{Mn}$ concentrations was sharply reduced while that for highest concentration continued at its high rate for about 7 days.

\section{Conclusions}

Hydrogen production by photosynthetic bacteria was enhanced three folds by fermenting the whey with $E$. coli prior to incubation with photosynthetic bacteria. Such productivity was further augmented by the addition of metal ions such as Mo, Fe and Mn or combinations thereof. The highest $\mathrm{H}_{2}$ production was achieved when $\mathrm{Mn}$ $(7.68 \mathrm{mg} / \mathrm{L})$ was added to treated whey containing $\mathrm{Fe}$ and Mo ions to give about $8500 \mathrm{ml} / 10$ days. The extent 
of $\mathrm{H}_{2}$ productivity was metal ions concentration dependent.

\section{REFERENCES}

[1] A. Margaritis and J. Vogrinetz, "The Effect of Glucose Concentration and $\mathrm{pH}$ on Hydrogen Production by Rhodopseudomonas Spheroids VM 81," International Journal of Hydrogen Energy, Vol. 8, No. 4, 1983, pp. 281-284 .

[2] H. Gest and M. D. Kamen, "Photoproduction of Molecular Hydrogen by Rhodospirillum Rubrum," Science, Vol. 109, No. 2840, 1949, pp. 558-559.

[3] L. Segers and W. Verstraete, "Conversion of Organic Acids to $\mathrm{H}_{2}$ by Rhodospirillaceae Grown with Glutamate or Dinitrogen as Nitrogen Source," Biotechnology and Bioengineering, Vol. 25, No. 12, 1983, pp. 2843-2853.

[4] M. D. Kamen and H. Gest, "Evidence for a Nitroginase System in the Photosynthetic Bacterium Rhodospirillum rubrum," Science, Vol. 109, No. 2840, 1949, p. 560.

[5] W. G. Zumft and D. J. Arp, "Increased Photo-Production of Hydrogen by Intracellular Accumulation of Nitrogenase in Phototrophic Bacteria," Naturwissenschaften, Vol. 68, No. 8, 1981, pp. 424-425.

[6] J. Meyer, B. C. Kelley and P. M. Vignais, "Effect of Light on Nitrogenase Function and Synthesis in Rhodopseudomonas Capsulata," Journal of Bacteriology, Vol. 136, No. 1, 1978, pp. 201-208.

[7] P. Hillmer and H. Gest, " $\mathrm{H}_{2}$ Metabolism in the Photosynthetic Bacterium Rhodopseudomonas Capsulata: H2 Production by Growing Cultures," Journal of Bacteriology, Vol. 129, 1977, pp. 724-731.

[8] P. Stevens, C. Vertonghen, P. de Vos and J. de Ley, "The Effect of Temperature and Light Intensity on Hydrogen Production by Different Rhodopseudomonas Capsulata strains," Biotechnology Letters, Vol. 6, No. 5, 1984, pp. 277-282.

[9] J. G. Ormerod, K. S. Ormerod and H. Gest, "Light Dependent Utilization of Organic Compounds and Photo- production of Molecular Hydrogen by Photosynthetic Bacteria: Relationship with Nitrogen Metabolism," $\mathrm{Ar}$ chive of Biochemistry and Biophysics, Vol. 94, 1961, pp. 449-463.

[10] Y. Jouanneau, S. Lebecque and P. M. Vignais, "Ammonia and Light Effect on Nitrogenase Activity in Nitrogen Limited Continuous Cultures of Rhodopseudomonas Capsulata. Role of Glutamine Synthease," Archive of Microbiology, Vol. 139, 1984, pp. 326-331.

[11] T. W. Jaffries, H. Timourian and R. L. Ward, "Hydrogen Production by Anabaena cylindrica: Effects of Varying Ammonium and Ferric Ions, pH, and Light," Applied and Environmental Microbiology, Vol. 35, No. 4, 1978, pp. 704-710

[12] P. F. Weaver, S. Lien and M. Seibert, "Photobiological Production of Hydrogen," Solar Energy, Vol. 24, No. 4, 1980, pp. 3-45.

[13] J. Wang, and W. Wan, "Factors Influencing Fermentative Hydrogen Production: A Review," International Journal of Hydrogen Energy, Vol. 34, No. 2, 2009, pp. 799-811.

[14] M. Frobisher, R. D. Hinsdill, K. T. Crabtree and C. R. Goodheart, "Fundamentals of Microbiology," W. B. Saunders Co., U.S.A., 1974.

[15] H. Zurrer and R. Bachofen, "Hydrogen Production by the Photosynthetic Bacterium Rhodospirillum Rubrum," Applied and Environmental Microbiology, Vol. 37, No. 5, 1979, pp. 789-793.

[16] F. M. Salih, "Improvement of Hydrogen Photoproduction from E. coli Pre-Treated Cheese Whey," International Journal of Hydrogen Energy, Vol. 14, No. 9, 1989, pp. 661663.

[17] I. K. Kapdan and F. Kargi, "Bio-Hydrogen Production from Waste Materials," Enzyme Microbial Technology, Vol. 38, No. 5, 2006, pp. 569-582.

[18] M. Yetisa, U. Gündüza, I. Eroglub, M. Yücela and L. Türkerc, "Photoproduction of Hydrogen from Sugar Refinery Wastewater by Rhodobacter Sphaeroides O.U. 001," International Journal of Hydrogen Energy, Vol. 25, No. 11, 2000, pp. 1035-1041. 